\title{
PENGARUH PEMBERIAN SELAI KACANG TANAH DENGAN SUBSTITUSI BEKATUL TERHADAP KADAR KOLESTEROL TOTAL TIKUS HIPERKOLESTEROLEMIA
}

\author{
Rahadiyan Nur Widiawan, Aryu Candra Kusumastuti*) \\ Program Studi Ilmu Gizi Fakultas Kedokteran Universitas Diponegoro \\ Jl.Dr.Sutomo No.18, Semarang, Telp (024) 8453708, Email : gizifk@undip.ac.id
}

\begin{abstract}
Background: Hypercholesterolemia is a condition that is the increasing of cholesterol level in blood serum has raised exceed normal. Cholesterol are useful, however, if the excessive of cholesterol has occurred, it could caused many degenerative disease such us coronary heart disease, cancer, hypertension and diabetic. Peanut butter with addition of rice bran is a product from peanut that has better in nutrition and antioxidant. This product is expected can decrease blood cholesterol because it contain MUFA, fiber, and antioxidant.

Method: This study is a experimental laboratory with randomized control groups pre-post design. Thirty four male Sprague Dawley strain rats aged 6-8 weeks that has \pm 80 gram of body weight and induced hypercholesterolemia from LPPT Universitas Gadjah Mada Yogyakarta. The dependent variables are change of rat's cholesterol level and the independent variable is intake of peanut butter with $30 \%$ substitution of rice bran in amount $21 \mathrm{~mm} / \mathrm{gram} /$ day. Strain, age, sex, feed, cage, and caging system of rat are controlled variable.

Result: Average of weight from both groups has increased. No significant different cholesterol total level from both groups after being intervene. Cholesterol total level of rat in treatment group after being intervene has decrease $2.91 \pm 8.51 \mathrm{mg} / \mathrm{dl}$. However, it wasn't significant ( $p>0.05$ ).

Conclusion: Administration peanut butter with $30 \%$ substitution of rice bran $21 \mathrm{mg} / \mathrm{gram} /$ day in two weeks can decrease $4.06 \%$ cholesterol total level of hypercholesterolemia rat but not significant.

Key words: butter; peanut; rice bran; cholesterol; hypercholesterolemia
\end{abstract}

\begin{abstract}
ABSTRAK
Latar belakang: Hiperkolesterolemia merupakan suatu kondisi dimana kolesterol dalam darah meningkat melebihi batas normal. Kolesterol sangat dibutuhkan untuk tubuh, namun apabila keberadaannya berlebih dalam tubuh maka dapat menimbulkan berbagai jenis penyakit degeneratif seperti penyakit jantung koroner, kanker, hipertensi, dan diabetes. Selai kacang tanah dengan substitusi bekatul adalah salah satu produk olahan kacang yang memiliki kelebihan dari segi zat gizi dan aktivitas antioksidannya. Produk ini diharapkan dapat menurunkan kadar kolesterol darah karena terdapat beberapa bahan makanan yang memiliki kandungan gizi yang dapat menurunkan kadar kolesterol darah seperti kandungan MUFA, serat, dan antioksidan.

Metode: Penelitian ini termasuk dalam ruang lingkup penelitian gizi medik dengan rancangan penelitian eksperimental laboratorik sesungguhnya jenis pre-post test desain randomized control groups pre-post design. Sebanyak 34 ekor tikus jantan Sprague Dawley umur 6-8 minggu dengan berat badan \pm 80 gram yang dibuat hiperkolesterolemia diperoleh dari LPPT Universitas Gadjah Mada, Yogyakarta. Variabel tergantung dalam penelitian ini adalah perubahan kadar kolesterol total tikus, sedangkan variabel bebas adalah asupan selai kacang tanah dengan substitusi bekatul 30\% sebanyak $21 \mathrm{mg} / \mathrm{gramBB} / \mathrm{hari}$. Galur, umur, jenis kelamin, pakan, kandang, dan sistem perkandangan tikus merupakan variabel terkontrol.

Hasil: Rerata berat badan subjek kedua kelompok memiliki kecenderungan meningkat dari awal hingga akhir penelitian. Tidak terdapat perbedaan bermakna kadar kolesterol total antar kelompok setelah diberi intervensi. Kadar kolesterol total tikus kelompok perlakuan setelah intervensi selai kacang dengan substitusi bekatul 30\% mengalami penurunan $2.94 \pm 8.51 \mathrm{mg} /$ dl namun tidak bermakna $(p>0.05)$.

Simpulan: Pemberian selai kacang dengan substitusi bekatul 30\% dengan dosis $21 \mathrm{mg} / \mathrm{gramBB} / \mathrm{hari}$ dalam waktu 2 minggu dapat menurunkan kadar kolesterol darah tikus hiperkolesterolemia sebesar $4.06 \%$ namun tidak bermakna. Kata kunci: selai; kacang; bekatul; kolesterol; hiperkolesterol
\end{abstract}

\section{PENDAHULUAN}

Hiperkolesterolemia merupakan suatu kondisi dimana kolesterol dalam darah meningkat melebihi batas normal yang ditandai dengan meningkatnya kadar LDL, trigliserida, dan kolesterol total. Kadar kolesterol normal dalam plasma orang dewasa sebesar 3,1 sampai $5,7 \mathrm{mmol} / \mathrm{l}$ atau 120 sampai $220 \mathrm{mg} / \mathrm{dl}^{1}{ }^{1}$ Adapun keadaan hiperkolesterolemia pada manusia dewasa terjadi bila konsentrasi kolesterol total $\geq 240 \mathrm{mg} / \mathrm{dl}$, trigliserida $\geq 150 \mathrm{mg} / \mathrm{dl}$, dan $\mathrm{LDL} \geq 160 \mathrm{mg} / \mathrm{dl}$. Kolesterol adalah prekusor senyawa steroid di dalam tubuh seperti kortikosteroid, hormon seks, asam empedu, dan vitamin D. Kolesterol merupakan substansi lemak hasil metabolisme yang 
banyak ditemukan dalam struktur tubuh manusia maupun hewan. ${ }^{2,3,4}$

Kolesterol sangat dibutuhkan untuk tubuh, namun apabila keberadaannya berlebih dalam tubuh maka dapat menimbulkan berbagai jenis penyakit degeneratif seperti penyakit jantung koroner, kanker, hipertensi, dan diabetes. ${ }^{3,4,5}$ Berdasarkan hasil Survey Kesehatan Rumah Tangga (SKRT) pada tahun 2001, kematian akibat penyakit jantung dan pembuluh darah sebesar $26,3 \%$ sedangkan kematian akibat penyakit jantung dan pembuluh darah di rumah sakit di Indonesia pada tahun 2005 sebesar $16,7 \% .^{6}$ Faktor yang mempengaruhi terjadinya hiperkolesterolemia antara lain pola diet sehari-hari, jenis kelamin, umur, dan genetik. Pengaturan pola diet sebagai pilar utama yang digunakan untuk menurunkan kolesterol adalah dengan mengurangi konsumsi lemak total dan lemak jenuh, meningkatkan asupan MUFA (Monounsaturated fatty acid) dan PUFA (Poliunsaturated fatty acid) serta meningkatkan asupan sayuran dan buah yang kaya akan serat dan antioksidan. ${ }^{8,9,10}$

Kacang merupakan salah satu sumber bahan makanan yang mengandung lemak tak jenuh yaitu MUFA dan juga merupakan salah satu makanan sumber serat. Berdasarkan penelitian, kandungan MUFA dan serat dalam kacang tanah dapat menurunkan kadar kolesterol darah. ${ }^{12}$ Kacang tanah juga mengandung fitosterol yang justru dapat menurunkan kadar kolesterol dan trigliserida, serta tetap menjaga HDL kolesterol. Konsumsi lemak $33 \%$ dari total energi selama 6 minggu yang bersumber dari makanan tinggi MUFA seperti kacang, minyak kacang, dan selai kacang dapat menurunkan kolesterol darah laki-laki dan wanita obes. ${ }^{14}$

Bekatul merupakan bahan makanan sumber serat yang tinggi seperti hemiselulosa. ${ }^{15}$ Kandungan serat kasar pada bekatul sebesar $7-10,1 \%$ dan serat pangan sebesar $21,2-30,2 \% .{ }^{16}$ Selain itu bekatul juga merupakan sumber asam lemak tak jenuh. ${ }^{16}$ Bekatul juga merupakan bahan makanan sumber antioksidan, diantaranya yaitu tokoferol, tokotrienol dan orizanol. ${ }^{11}$ Beberapa penelitian menunjukkan bahwa antioksidan tokotrienol dan oryzanol pada bekatul menghambat sintesis kolesterol dan menurunkan kadar kolesterol. ${ }^{10,11,19}$ Dengan adanya kandungan gizi tersebut, bekatul dapat menurunkan kadar kolesterol darah. Suatu penelitian membuktikan bahwa suplementasi bekatul sebesar $57 \%$ dapat menurunkan kadar kolesterol darah $17,28 \% .^{16}$

Selai kacang tanah dengan substitusi bekatul adalah salah satu produk olahan kacang yang memiliki kelebihan dari zat gizi dan aktivitas antioksidannya. Produk teknologi pangan ini adalah produk selai dari penelitian sebelumya yang dibuat dari bahan dasar kacang tanah yang kemudian disubstitusi bekatul merah (bekatul dari beras merah) dengan tujuan untuk meningkatkan kandungan zat gizi dan aktivitas antioksidannya sehingga bermanfaat bagi kesehatan konsumen. ${ }^{11}$ Produk ini dapat menurunkan kadar kolesterol darah karena terdapat beberapa bahan makanan yang memiliki kandungan gizi yang dapat menurunkan kadar kolesterol darah, seperti kandungan MUFA, serat, dan antioksidan. ${ }^{13,16,18}$ Penggunaan bekatul sebagai substitusi bahan selai kacang meningkatkan aktivitas antioksidan dan mempengaruhi kandungan gizi pada selai salah satunya menurunkan kandungan lemak dan meningkatkan kandungan serat sehingga produk ini diharapkan menjadi alternatif produk pangan karena selain rasa yang dapat diterima tetapi juga manfaatnya yang baik bagi kesehatan serta dapat diproduksi dalam skala rumah tangga dengan proses produksi yang lebih efisien.

Berdasarkan uraian di atas, sebagai studi awal, penulis ingin meneliti pengaruh pemberian selai kacang dengan substitusi bekatul 30\% sebanyak $21 \mathrm{mg} / \mathrm{gramBB} / \mathrm{hari}$ terhadap kadar kolesterol tikus galur Sprague Dawley hiperkolesterolemia selama 2 minggu. Penentuan dosis didasarkan pada anjuran konsumsi serat pada manusia yaitu 20-35 g/hari. ${ }^{3}$ Penggunaan tikus sebagai subjek penelitian karena penelitian ini merupakan studi awal suatu produk baru yang belum diketahui efek lain yang akan timbul setelah pemberian terhadap subjek penelitian. Tikus juga mempunyai sifat lebih tahan terhadap perlakuan, omnivora, tidak dapat muntah, serta beberapa variabel seperti galur, umur, jenis kelamin, pakan, kandang, dan sistem perkandangan tikus dapat dikontrol. ${ }^{20}$

\section{METODE PENELITIAN}

Ruang lingkup penelitian termasuk dalam penelitian gizi medik dengan rancangan penelitian eksperimental laboratorik sesungguhnya jenis prepost test desain randomized control groups pre-post design. ${ }^{21}$ Sebanyak 34 ekor tikus jantan Sprague Dawley umur 6-8 minggu dengan berat badan \pm 80 gram diperoleh dari LPPT Universitas Gadjah Mada, Yogyakarta. ${ }^{22}$ Setelah diadaptasikan pada kandang percobaan selama 1 minggu, tikus-tikus tersebut dibuat hiperkolesterol dan selanjutnya dibagi secara acak menjadi 2 kelompok. Perhitungan jumlah sampel minimal menggunakan rumus besar sampel experimental dari freeder di 
mana (t-1) (r-1) $\geq 15$, t merupakan jumlah kelompok perlakuan sedangkan $\mathrm{r}$ merupakan besar sampel setiap kelompok perlakuan, sehingga didapatkan sampel minimal sebanyak 16 ekor tiap kelompok yang selanjutnya ditambah satu ekor tiap kelompok menjadi 17 ekor untuk menghindari drop out. Kriteria eksklusi sampel yaitu tikus mati saat penelitian berlangsung, tikus lemas, menolak makan, dan tikus mengalami penurunan berat badan mencapai < 60 gram. Tikus diukur berat badannya 3 hari sekali atau 10 kali pengukuran selama penelitian berlangsung (satu kali diawal penelitian, empat kali selama intervensi pakan hiperkolesterol, dan lima kali selama intervensi selai kacang tanah dengan substitusi bekatul).

Variabel tergantung dalam penelitian ini adalah perubahan kadar kolesterol total tikus, sedangkan variabel bebas adalah asupan selai kacang tanah dengan substitusi bekatul 30\% sebanyak $21 \mathrm{mg} / \mathrm{gramBB} /$ hari. Galur, umur, jenis kelamin, pakan, kandang, dan sistem perkandangan tikus merupakan variabel terkontrol.

Tikus diaklimatisasi di dalam kandang individu selama satu minggu dengan diberikan pakan standar. Pakan standar diberikan setiap hari sebanyak 6\% dari berat badan tikus oleh LPPT Universitas Gadjah Mada, Yogyakarta. ${ }^{22,23}$ Suhu ruangan berkisar antara $28-32^{\circ} \mathrm{C}$ dan siklus pencahayaan 12 jam. Pemberian pakan standar dilakukan selama 1 minggu, kemudian sebelum diambil darahnya tikus dipuasakan selama 12 jam, selanjutnya sampel darah diambil sebanyak $1,5 \mathrm{ml}$ melalui pleksus retroorbitalis untuk menentukan kadar fraksi lipid serum darah yang digunakan sebagai standardisasi tikus percobaan. ${ }^{24}$ Pakan standar terdiri atas air, protein kasar, lemak kasar, serat kasar, abu, kalsium, fosfor, coccidiostat, dan antibiotik.

Setelah aklimatisasi, seluruh tikus diberikan penambahan pakan tinggi kolesterol disamping pakan standar untuk membuat tikus menjadi hiperkolesterol. Pakan tinggi kolesterol adalah otak sapi yang telah dikukus dan diblender. Bubur otak sapi diberikan dengan cara sonde sebanyak $2 \mathrm{mg} / \mathrm{ekor} / \mathrm{hari}$ selama 2 minggu. Pada penelitian sebelumnya, dosis tersebut dapat meningkatkan secara bermakna kadar kolesterol total sebanyak $70,45 \%$, kolesterol LDL $68 \%$ dan trigliserida $64,70 \% .{ }^{25}$ Tikus dipuasakan selama 12 jam, selanjutnya sampel darah diambil sebanyak 1,5 $\mathrm{ml}$ melalui pleksus retroorbitalis untuk pemeriksaan fraksi lipid serum keadaan hiperkolesterolemia awal perlakuan. ${ }^{24}$

Tikus dibagi menjadi 2 kelompok masingmasing 17 ekor tikus yang ditentukan secara acak selanjutnya tikus dikandangkan secara individual. Kelompok kontrol mendapatkan pakan standar sehari sebanyak $6 \%$ dari berat badan tikus. Kelompok perlakuan mendapatkan pakan total sehari sebanyak $6 \%$ dari berat badan tikus yang terdiri dari selai kacang tanah dengan substitusi bekatul $21 \mathrm{mg} / \mathrm{gramBB} / \mathrm{hr}$ dan pakan standar. Selama perlakuan, dilakukan pengontrolan berat badan setiap 3 hari sekali atau sekitar 10 kali pengukuran berat badan selama perlakuan. Penentuan dosis didasarkan pada anjuran konsumsi serat pada manusia yaitu 20-35 g/hari. ${ }^{3}$ Berdasarkan perhitungan, maka ditentukan dosis selai kacang dengan substitusi bekatul sebesar 21 $\mathrm{mg} /$ gramBB/hari selama 14 hari. ${ }^{26}$ Selai kacang yang akan diberikan diencerkan dengan air agar bisa diberikan secara sonde. Setelah pemberian perlakuan, tikus dipuasakan selama 12 jam, selanjutnya sampel darah diambil sebanyak $1,5 \mathrm{ml}$ melalui pleksus retroorbitalis untuk pemeriksaan fraksi lipid serum keadaan hiperkolesterolemia setelah perlakuan. ${ }^{24}$

Pengukuran kadar kolesterol dilakukan di LPPT Universitas Gajah Mada, Yogyakarta. Kadar kolesterol total diukur dengan metode CHOD-PAP dan menggunakan pereaksi kit. ${ }^{27}$ Kolesterol diukur setelah dihidrolisis dan dioksidasi secara enzimatis. Kadar kolesterol awal adalah kadar kolesterol sebelum perlakuan. Kadar kolesterol total akhir adalah kadar kolesterol setelah perlakuan.

Data yang terkumpul merupakan data primer hasil pemeriksaan kadar kolesterol total. Hasilnya merupakan perbandingan dari kelompok perlakuan dengan kelompok kontrol. Data yang diperoleh diolah dengan program komputer. Analisis bivariat digunakan untuk mengetahui hubungan masing-masing variabel. Data tersebut diuji normalitasnya dengan uji Saphiro Wilk. Perbedaan kadar kolesterol total sebelum dan sesudah perlakuan diuji dengan paired t-test jika distribusi data normal dan jika data tidak normal dilakukan uji statistik non parametrik Wilcoxon. Perbedaan pengaruh dari kedua kelompok perlakuan dianalisis menggunakan uji independent $t$-test jika data terdistribusi normal. Jika didapatkan distribusi data yang tidak normal dilakukan uji Mann-Whitney. ${ }^{28}$

\section{HASIL \\ Karasteristik Subjek}

Penelitian dilakukan pada 34 ekor tikus Sprague Dawley jantan yang dipelihara dalam kandang individu dengan suhu ruangan berkisar antara $28-32^{\circ} \mathrm{C}$ dan siklus pencahayaan $12 \mathrm{jam}$. Pembersihan kandang dan pemeliharaan dilakukan 
setiap hari oleh penjaga laboratorium. Pemberian pakan dilakukan setiap hari. Pakan habis dimakan oleh tikus.

Penimbangan berat badan dilakukan setiap 3 hari sekali atau 10 kali pengukuran selama penelitian berlangsung. Pengukuran pertama dilakukan pada awal penelitian setelah aklimatisasi (hari 1). Pengukuran kedua (hari 4), ketiga (hari 7), keempat (hari 10), kelima (hari 13) diukur saat pemberian pakan hiperkolesterol, pengukuran keenamsampai kesepuluh diukur selama intervensi selai kacang tanah dengan substitusi bekatul (hari 16 sampai hari 28).

Gambaran rerata berat badan ditunjukkan pada gambar berikut.

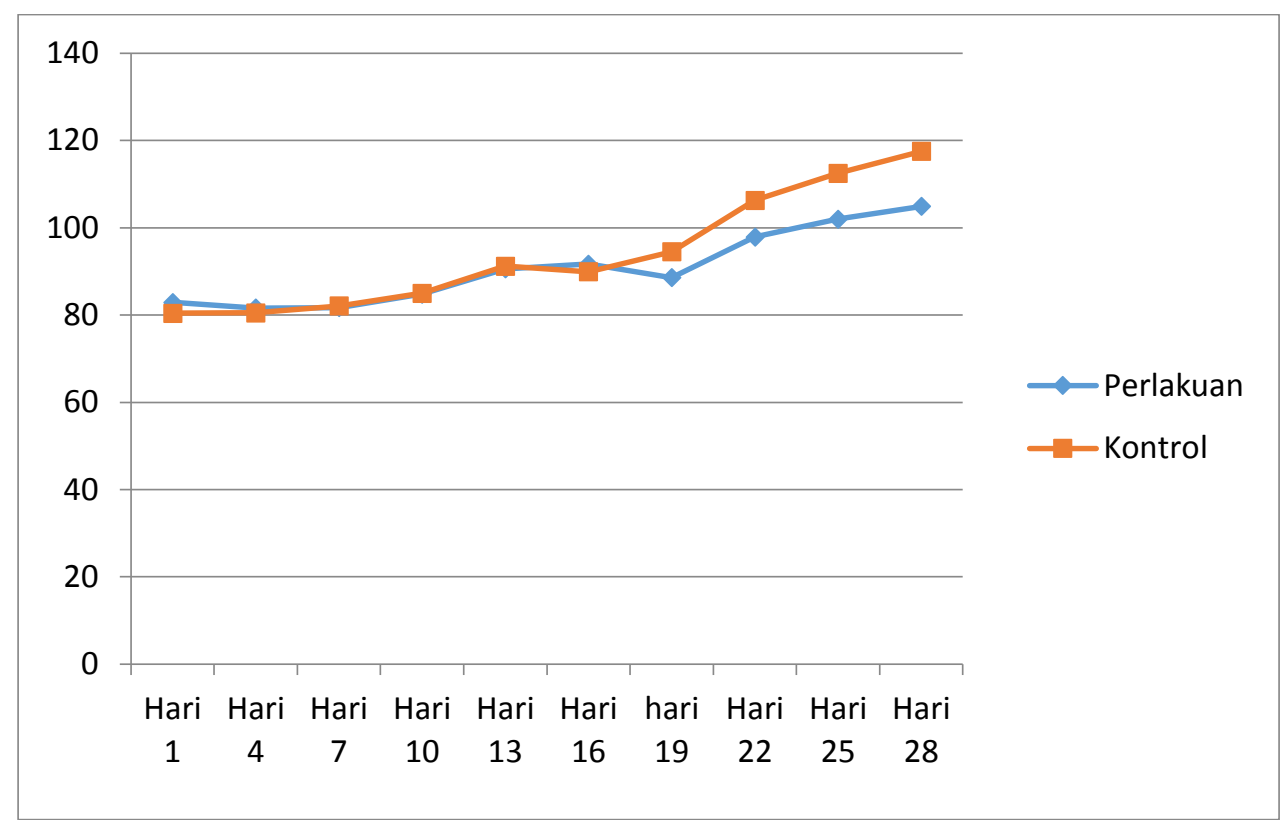

Gambar 2. Grafik Berat BadanTikus (gram)

Gambar 2 menunjukkan bahwa rerata berat badan subjek kedua kelompok memiliki kecenderungan meningkat dari awal hingga akhir penelitian yang tentunya berbanding lurus dengan asupan makanannya karena jumlah pemberian pakan ditentukan dengan menghitung $6 \%$ dari berat badan tikus.

Rerata berat badan tikus pada awal penelitian pada kelompok kontrol sebesar $80.43 \pm 12.11$ gram, sedangkan kelompok perlakuan sebesar $82.89 \pm 13.86$ gram, sehingga apabila dilakukan uji statistik, tidak terdapat perbedaan yang bermakna antar kedua kelompok ( $p>0.05)$. Selama penelitian berlangsung, kelompok kontrol mengalami kenaikan berat badan sebesar $46.13 \%$ (37.11 \pm 11.81 gram), sedangkan kelompok perlakuan mengalami kenaikan $26.61 \%$ (22.06 \pm 12.05 gram), sehingga apabila dilakukan uji statistik, terdapat perbedaan berat badan bermakna antar kedua kelompok $(p<0.05)$.

Tabel 1. Hasil Analisis Kadar Kolesterol Total Tikus

\begin{tabular}{cccc}
\hline Kelompok & Perlakuan & Kontrol & p value \\
\hline $\begin{array}{c}\text { Sebelum Pakan } \\
\text { Hiperkolesterol }\end{array}$ & $69.66 \pm 7.58$ & $67.81 \pm 7.99$ & 0.493 \\
\hline $\begin{array}{c}\text { Setelah Pakan } \\
\text { Hiperkolesterol/Sebelum } \\
\text { Intervensi Selai }\end{array}$ & $72.41 \pm 8.47$ & $71.12 \pm 13.67$ & 0.743 \\
\hline Setelah Intervensi Selai & $69.47 \pm 7.71$ & & \\
\hline$\Delta \mathbf{I}_{1}$ & $2.75 \pm 5.91$ & $70.37 \pm 10.17$ & 0.773 \\
\hline$\Delta \mathbf{I}_{2}$ & $-2.94 \pm 8.51$ & $3.31 \pm 14.55$ & 0.884 \\
& $(\mathrm{p}=0.173)$ & $-0.75 \pm 10.04$ & 0.497 \\
& & & \\
\hline
\end{tabular}

Keterangan :

- $\Delta \mathrm{I}_{1}$ adalah selisih antara sebelum Pemberian Pakan Hiperkolesterol dan sesudah Pemberian Pakan Hiperkolesterol/ sebelum Intervensi Selai

- $\quad \Delta \mathrm{I}_{2}$ adalah selisih antara sesudah Pemberian Pakan Hiperkolesterol/ sebelum Intervensi Selai dan Setelah Intervensi Selai 
Tabel 1 menunjukkan bahwa rerata kadar kolesterol total sebelum intervensi pakan hiperolesterol antar kedua kelompok tidak terdapat perbedaan yang bermakna ( $p>0.05)$. Rerata kadar kolesterol total kelompok perlakuan mengalami peningkatan tidak bermakna sebesar $2.75 \pm 5.91$ $\mathrm{mg} / \mathrm{dl}(3.94 \%)(p>0.05)$. Rerata kadar kolesterol total kelompok kontrol mengalami peningkatan sebesar $3.31 \pm 14.55 \mathrm{mg} / \mathrm{dl}(4.88 \%)$ namun tidak bermakna $(p>0.05)$.

Tabel 1 juga menunjukkan bahwa rerata kadar kolesterol total setelah intervensi pakan hiperkolesterol antar kedua kelompok tidak terdapat perbedaan yang bermakna ( $p>0.05$ ). Sama halnya dengan rerata kadar kolesterol total setelah intervensi selai kacang dengan substitusi bekatul tidak ada perbedaan bermakna antar kedua kelompok perlakuan $(p>0.05)$. Setelah Intervensi selai kacang dengan substitusi bekatul, rerata kadar kolesterol total kelompok perlakuan mengalami penurunan sebesar $2.94 \pm 8.51 \mathrm{mg} / \mathrm{dl}(4.06 \%)$ namun tidak bermakna $(p>0.05)$. Sedangkan kelompok perlakuan mengalami penurunan tidak bermakna sebesar $1 \%$ atau $0.75 \mathrm{mg} / \mathrm{dl} \pm 10.04(p>0.05)$. Tidak ada perbedaan penurunan yang bermakna antara kelompok perlakuan dengan kontrol setelah intervensi selai $(p>0.05)$.

\section{PEMBAHASAN \\ Karakteristik Subjek}

Grafik berat badan pada Gambar 2 menunjukkan bahwa selama penelitian rerata berat badan subjek meningkat. Peningkatan berat badan terjadi diantaranya karena jumlah pemberian pakan yang sesuai dengan kebutuhan, usia tikus yang masih 6-8 minggu sehingga seiring bertambahnya usia, pertumbuhan dan peningkatan berat badan masih dapat terjadi, dan pemberian pakan hiperkolesterol yang kemungkinan mempengaruhi peningkatan berat badan tikus. ${ }^{20-23,29}$ Namun, berdasarkan Gambar 2, pada pengukuran 7 sampai dengan 10 dimana pada saat itu kedua kelompok diberikan intervensi yang berbeda, terjadi perbedaan perubahan berat badan yang bermakna dimana rerata berat badan kelompok kontrol mengalami kenaikan mencapai 117.54 \pm 15.21 gram, lebih tinggi dibandingkan dengan kelompok perlakuan (104.95 \pm 13.60 gram). Hal ini kemungkinan dapat terjadi karena kedua kelompok diberi perlakuan yang berbeda dimana kelompok perlakuan diberi perlakuan sonde yang bisa mempengaruhi tingkat stress tikus sehingga menghambat kenaikan berat badan. ${ }^{20}$ Kemungkinan lainnya yaitu tidak diketahui kandungan energi dan gizi pakan standar karena tidak dilakukan pengujian sehingga dimungkinkan jumlah energi pakan yang diberikan kepada kelompok kontrol dengan yang diberikan pada kelompok perlakuan berbeda.

Walaupun rerata berat badan seluruh tikus lebih kecil dibandingkan dengan berat badan tikus normal di usianya ( $\pm 150-250 \mathrm{~g})$, namun tikus tidak mengalami gangguan kesehatan, lemas, ataupun tampak kurus.

\section{Peningkatan Kadar Kolesterol Kedua Kelompok Setelah Pemberian Pakan Hiperkolesterol}

Pada penelitian ini, seluruh subjek diberi pakan hiperkolesterol berupa otak sapi yang telah dikukus dan diblender. Bubur otak sapi diberikan dengan cara sonde sebanyak $2 \mathrm{mg} /$ ekor/hari selama 2 minggu. Penelitian terdahulu menunjukkan bahwa dosis tersebut dapat meningkatkan secara bermakna kadar kolesterol total sebanyak 70,45\%, kolesterol LDL $68 \%$ dan trigliserida $64,70 \% .{ }^{25}$ Pada tabel 1 dapat terlihat bahwa rerata kadar kolesterol kedua kelompok mengalami peningkatan walaupun tidak bermakna. Kenaikan yang tidak bermakna ini kemungkinan terjadi karena kondisi subjek yang telah masuk dalam kategori hiperkolesterolemi sebelum diberi pakan hiperkolesterol (Kadar kolesterol total tikus normal $10-54 \mathrm{mg} / \mathrm{dl}$ ). ${ }^{30}$ Rerata kadar kolesterol kelompok perlakuan dan kontrol sebelum diberi pakan hiperkolesterol masingmasing sebesar $69.66 \pm 7.58 \mathrm{mg} / \mathrm{dl}$ dan $67.81 \pm 7.99$ $\mathrm{mg} / \mathrm{dl}$. Kemungkinan lainnya yaitu waktu pemberian intervensi yang kurang lama.

Pengaruh Selai Kacang dengan Substitusi Bekatul 30\% terhadap Kadar Kolesterol Total

Berdasarkan Tabel 1, dapat dilihat bahwa rerata kadar kolesterol total kelompok perlakuan sebelum dan setelah pemberian selai mengalami penurunan sebesar $2.94 \pm 8.51 \mathrm{mg} / \mathrm{dl}(4.06 \%)$ namun tidak bermakna bermakna secara statistik. Penurunan tidak bermakna juga terjadi pada kelompok kontrol namun angka penurunannya lebih rendah dari pada kelompok perlakuan yaitu sebesar $1 \%$ atau $0.75 \mathrm{mg} / \mathrm{dl} \pm 10.04$. Hal ini terjadi karena pakan standar yang kemungkinan mengandung zat yang dapat menurunkan kadar kolesterol total tikus. Selain itu, pada saat intervensi selai, kelompok kontrol hanya diberi pakan standar saja dimana pakan tinggi kolesterol tidak diberikan lagi sehingga kemungkinan mempengaruhi kadar kolesterol tikus.

Angka penurunan rerata kadar kolesterol kelompok perlakuan lebih besar dibandingkan kelompok kontrol. Hal ini kemungkinan dipengaruhi oleh kandungan gizi selai kacang dengan substitusi bekatul. Kandungan MUFA dalam selai menurunkan kadar kolesterol karena pada MUFA didominasi oleh ikatan konfigurasi cis. 
Konfigurasi cis dapat menghambat absorbsi kolesterol dalam intestinum dan strukturnya lebih stabil sehingga tidak mudah dioksidasi. Oksidasi asam lemak dapat menyebabkan kerusakan seluler seperti lipoprotein plasma, sehingga menyebabkan LDL teroksidasi yang dapat menimbulkan plak aterosklerosis. ${ }^{13}$ Kacang tanah sebagai bahan utama selai juga mengandung fitosterol yang justru dapat menurunkan kadar kolesterol dan trigliserida, dengan cara menahan penyerapan kolesterol dari makanan yang disirkulasikan dalam darah dan mengurangi penyerapan kembali kolesterol dari hati. Kemudian kandungan serat dalam selai dapat menurunkan kadar kolesterol dengan mekanisme penghambatan kerja enzim HMG-KoA reduktase sehingga sintesis kolesterol menurun. Serat larut air akan mengikat lemak, protein, dan karbohidrat yang mengakibatkan proses pencernaan dan penyerapan lemak menjadi terganggu. Serat menghambat penyerapan kolesterol dalam usus dan menghambat sintesis kolesterol dalam hati. ${ }^{16}$ Adanya kandungan antioksidan dalam selai juga dapat menurunkan kadar kolesterol dengan cara menghambat dan mencegah kerusakan LDL karena oksidasi yang akhirnya dapat menurunkan kolesterol darah. ${ }^{18}$ Pemberian intervensi selai kacang dengan substitusi dapat menurunkan kadar kolesterol tikus kelompok perlakuan, namun apabila kadar kolesterol kelompok perlakuan dibandingkan dengan kelompok kontrol, tidak terdapat perbedaan yang bermakna. Hal ini terjadi karena kemungkinan waktu intervensi yang kurang lama atau dosis pemberian yang kurang tepat. Penelitian ini merupakan penelitian awal tentang pengaruh suatu produk terhadap kadar kolesterol total darah sehingga belum terdapat dasar tentang pemberian dosis dan jangka waktu pemberian yang tepat.

\section{SIMPULAN}

Pemberian selai kacang dengan substitusi bekatul 30\% dengan dosis $21 \mathrm{mg} / \mathrm{gramBB} / \mathrm{hari}$ dalam waktu 2 minggu dapat menurunkan kadar kolesterol darah tikus hiperkolesterolemia sebesar $4.06 \%(2.94 \pm 8.51 \mathrm{mg} / \mathrm{dl})$ namun tidak bermakna $(p>0.05)$.

\section{SARAN}

Pada penelitian selanjutnya, perlu dilakukan uji ulang secara lengkap kandungan zat gizi pada pakan standar, pakan hiperkolesterolemia, dan pakan selai kacang dengan substitusi bekatul $30 \%$ yang akan diintervensikan agar optimal dalam penentuan dosis yang akan diberikan pada subjek. Perlu dilakukan penelitian serupa dengan jangka waktu intervensi dan dosis yang berbeda. Pada kelompok kontrol, perlu diberikan sonde air putih agar tingkat stress antar kelompok kemungkinan sama.

\section{DAFTAR PUSTAKA}

1. Dasuki, M. Shoim and Risanty, Nurina. Pengaruh Kitosan Olahan Kulit Udang Putih terhadap Penurunan Kadar Trigliserida Plasma Tikus Putih (Rattus norvegicus). Biomedika, 1 (2). pp. 37-41. ISSN 2085-8345. 2009.

2. Kathleen MB, Mayes PA. Sintesis, Pengangkutan, dan Ekskresi Kolesterol. Dalam: Murray RK, Granner DK, Rodwell VW, editor. Biokimia harper $27^{\text {th }}$ ed. Jakarta: EGC; 2006.

3. Hernawati. Peranan Berbagai Sumber Serat dalam Dinamika Kolesterol pada Individu Hiperkolesterolemia dan Normokolesterolemia. Jurusan Pendidikan Biologi. FPMIPA. Universitas Pendidikan Indonesia. Bandung.

4. Heather HF, Lisa AB, Alan EM. Practical Application in Sports Nutrition. USA : Jones and Bartlett Publishers, Inc, 2008.

5. Scott MG, et al. Cholesterol Lowering in the Elderly Population.ARCH INTERN MED/VOL 159, AUG 9/23, 1999

6. Andreas A. Aspek Medis Penyakit Jantung dan Pembuluh Darah. Dalam : Pertemuan Ilmiah Nasional ke-3; 2007 juli 19-21; Semarang. Asosiasi Dietisien Indonesia DPD Jawa Tengah; 2007.

7. MH Pittler, NC Abbot, EF Harkness, E Ernst. Randomized, Double-Blind Trial of Chitosan for Body Weight Reduction. European Journal of Clinical Nutrition (1999) 53, 379 \pm 381

8. Penny M Kris-Etherton et al. Highmonounsaturated Fatty Acid Diets Lower Both Plasma Cholesterol and Triacylglycerol Concentration. American Journal Clinical Nutrition 1999;70:1009-15 USA.

9. Nainggolan O dan Adimunca C. Diet Sehat dengan Serat. Cermin Dunia Kedokteran 2005; 147: 43-6.

10. Evy D. Aktivitas Antioksidan Minyak Bekatul Padi Awet dan Fraksinya secara In Vitro. 2004; 15(1)

11. Susanto, Dwi. 2011. Potensi Bekatul Sebagai Sumber Antioksidan dalam Produk Selai Kacang. Program Studi Ilmu Gizi UNDIP. Semarang.

12. Tuminah, Sulistyowati. Efek Asam Lemak Jenuh dan Lemak Tak Jenuh "Trans" Terhadap Kesehatan. Media Peneliti dan Pengenmbang Kesehatan. Volume XIX. Seplemen II. 2009.

13. Haryanti, H.W. 2012. Potensi Omega 9-Asam Oleat pada Daging Buah Alpukat dalam Penurunan Kadar Kolesterol Serum Darah. Jurusan Pendidikan Biologi IKIP PGRI. Semarang.

14. Pelkman et al. Effect of Moderate-fat (From Monounsaturated Fat) and Low-fat Weight-loss Diets on The Serum Lipid Profile in Overweight and Obese Men and Women. USA. American Journal of Nutrition 2004;79;204-12.

15. Mark Kestin, Ray Moss, Peter M Clifton, and Paul J Nestel. Comparative Effect of Three Cereal Brans 
on Plasma Lipids, Blood Pressure, and Glucose Metabolism in Midly Hipercholesterolemic Men. American Journal Clinical Nutrition 1990;52:661-6 USA.

16. Hernawati dkk. Perbaikan Parameter Lipid Darah Mencit Hiperkolesterolemia dengan Suplemen Pangan Bekatul. Institut Pertanian Bogor. MKB, Volume 45 No. 1. 2013.

17. Sumardika, I Wayan. Jawi, I Made. Ekstrak Air Daun Ubijalar Ungu Memperbaiki Profil Lipid dan Meningkatkan Kadar SOD Darah Tikus yang Diberi Makanan Tinggi Kolesterol. Universitas Udayana. Jurnal Ilmiah Kedokteran. MEDICINA. Volume 43 Nomor 2 Mei 2012.

18. Andriani, Yosie. Uji Aktivitas Antioksidan Ekstrak Betaglukan dari Saccharomyces cerevisiae. Universitas Bengkulu. Jurnal Gradien Vol 3 No. 1 Januari 2007 : 226-230.

19. Asaf AQ, David MP, Judith OH, Jan R. Novel Tocotrienols of Rice Bran Suppress Cholesterogenesis in Hereditary Hypercholesterolemic Swine, JN, 2001

20. Malole, M.B.M dan Pramono, C.S.U. 1989. Penggunaan Hewan-Hewan Laboratorium. Departemen Pendidikan dan Kebudayaan, Dirtjen Pendidikan Tinggi - Pusat Antar Universitas Bioteknologi. IPB. Bogor. Hal. 64. 77

21. Suyatno. Menghitung Besar Sampel Penelitian Kesehatan Masyarakat. Semarang. UNDIP. 2009.

22. Vinerean HV. Rats-Biology and Husbandry. Laboratory Animal Research. Florida International University.(diakses tanggal18 Maret 2014).

23. Riyantie, Novie. Pengaruh Defisiensi Pakan terhadap Perubahan Beberapa Berat Organ Tikus Betina Dewasa (Rattus sp.) [Skripsi]. Bagian Fisiologi dan Farmakologi. Fakultas Kedokteran Hewan. Institut Pertanian Bogor. 2001.

24. Institutional Animal Care and Use Committee. Blood Sampling in Mice and Rats. University of Washington; 2012.

25. Riyanto S. Pengaruh Pemberian Yoghurt Kedelai Hitam (Black Soyghurt) terhadap Profil Lipid Serum Hiperkolesterolemia.[Skripsi]. Fakultas kedokteran Universitas Diponegoro; 2011.

26. Yuniastuti A. Pengaruh pemberian susu fermentasi lactobacillus casei galur shirota terhadap kadar fraksi lipid serum tikus hiperkolesterolemi. Tesis Program Pasca Sarjana Magister Ilmu Biomedik. FK UNDIP Semarang. 2004.

27. E. Prangdimurti, dkk. Metode Evaluasi Nilai Biologis Karbohidrat dan Lemak. Modul $e$ Learning ENBP, Departemen Ilmu \& Teknologi Pangan-Fateta-IPB 2007.

28. Dahlan, M Sopiyudin. Statistik Untuk Kedokteran dan Kesehatan. Salemba Medika. Jakarta. 2011.

29. Karyadi E. Kiat Mengatasi Diabetes, Hiperkolesterolemia, Stroke. Jakarta: PT Intisari Mediatama; 2006: 53-7,59-61,63-4,73.

30. Harini, M., DA, Okid. 2009. Blood Cholesterol Level of Hypercgolesterolemia Rat (Rattus norvegicus) After VCO Treatment. Journal Bioscience Vol 1 No 2 : 53-58 